\title{
La intervención en la adopción colectiva de acuerdos en una sociedad y responsabilidad penal ${ }^{*}$
}

\author{
Iván Meini Méndez**
}

\section{Planteamiento}

1. La responsabilidad penal de los miembros del directorio de una sociedad, a consecuencia de la aprobación de un acuerdo antijurídico, o por no aprobar uno debido, se encuentra estrechamente vinculada a la responsabilidad por el producto. ${ }^{1}$ Pero la responsabilidad penal derivada de las decisiones colegiadas no es un tema privativo de la responsabilidad por el producto, ni siquiera de la responsabilidad empresarial, aunque se discuta principalmente en los delitos societarios (artículo $198 \mathrm{CP}$ ). Su estudio se da también en la responsabilidad penal funcionarial en la Administración Pública, ${ }^{2}$ e incluso podría plantearse en la criminalidad organizada. ${ }^{3}$

- Abreviaturas utilizadas: $A D P C P$ : Anuario de Derecho penal y Ciencias penales; $C D$ : Cuadernos de Derecho Judicial; CP: Código Penal; JZ: Juristenzeitung; n.m.: número marginal; LGS: Ley general de sociedades; NFP: Nuevo Foro Penal; NIW: Neue Juristische Wochenschritf; NStZ: Neue Zeitschrift für Strafrecht; PE: Parte especial; PG: Parte general; RDPC: Revista de Derecho penal y Criminología; RP: Revista Penal; RTDPE: Rivista trimestrale di diritto penale dell'economia.

** Profesor de Derecho Penal, Universidad Católica del Perú

1 En este sentido, KUHLEN, Lothar. "Grundfragen der strafrechtlichen Produkthaftung". IZ, 1994, p. 1146; HILGENDORF, Eric. "Fragen der Kausalität bei Gremienentscheidungen am Beispiel des Lederspray- Urteil», NStZ 1994, p. 561; SCHMIDT-SALZER, Joachim. "Verbraucherschutz, Produkthaftung, Umwelthaftung, Unternehmensverantwortung", NIW, 1994, p. 1309. Es sintomático, en doctrina, el caso "Laderspray" en Alemania, Sentencia del BGH de 6 de julio de 1990 (BHCSt. 37, 106, en N/W, 1990, pp. 2560 y ss.)

2 Rodrícuez MONTAÑÉs, Teresa. "Algunas reflexiones acerca del problema causal y la autoría en los supuestos de adopción de acuerdos antijurídicos en el seno de órganos colegiados», $R D P C$, número extraordinario 1,2000, p. 171. Piénsese en el caso en que la ley castiga al efuncionario público que otorga licencia de funcionamiento para cualquier actividad industrial o el que, a sabiendas, informa favorablemente para su otorgamiento sin observar las exigencias [...]” (artículo $306 \mathrm{CP}$ ), en donde podría tratarse de varios funcionarios reunidos en consejo o en asamblea. 
2. En el ámbito empresarial, que es el que aquí interesa, la evolución de las grandes sociedades anónimas ha consagrado de facto un fortalecimiento del poder personal de los administradores, en detrimento del poder y del control de la junta general (manager's revolution). ${ }^{4}$ Las causas de esta coyuntura se pueden resumir en que a los administradores les corresponde la dirección de la explotación de la empresa; ostentan, a diferencia del común de los accionistas, los conocimientos técnicos necesarios para la gestión de la sociedad; $y$, al grueso de los accionistas les interesa más el reparto de utilidades que la marcha, gestión y control de la sociedad. ${ }^{5}$ No es de extrañar, pues, que en este contexto la administración de las sociedades mercantiles esté concentrada en pocas manos y, a su vez, organizada en órganos colectivos $^{6}$ (v.g. el directorio). Los acuerdos que adopta, y las decisiones que toma una reducida minoría así organizada, determinan luego el curso y posterior éxito o fracaso de la gestión empresarial.

3. Cuando los acuerdos colectivos se adoptan respetando los requisitos de fondo y forma que prescribe la legislación mercantil y/o societaria en general, y los estatutos de la sociedad en particular, no hay problema alguno. Sin embargo, cuando se trata de acuerdos contrarios al derecho, el diagnóstico varía. La propia LGS regula al detalle, en sus artículos 177 a 184, la responsabilidad mercantil de los directores. Concretamente, y para lo que aquí interesa, el artículo 177 LGS refiere que

los directores responden, ilimitada y solidariamente, ante la sociedad, los accionistas y los terceros por los daños y perjuicios que causen por los acuerdos o actos contrarios a la ley, al estatuto o por los actos realizados con dolo, abuso de facultades o negligencia grave. [...] Los directores son asimismo solidariamente responsables con los directores que los hayan precedido por las irregularidades que éstos hubieran cometido si, conociéndolas, no las denunciare por escrito a la junta general.

El artículo 170 LGS in fine establece que «el director que quiera salvar su responsabilidad por algún acto o acuerdo del directorio debe pedir que

3 En este sentido, Gimbernat, Enrique "¿Las exigencias dogmáticas fundamentales hasta ahora vigentes de una parte general son idóneas para satisfacer la actual situación de la criminalidad, de la medición de la pena y del sistema de sanciones? (Responsabilidad por el producto, accesoriedad administrativa del derecho Penal y decisiones colegiadas)». En: Modernas tendencias en la ciencia del derecho penal y en la criminología, Madrid: UNED, 2001, pp. 364 y ss.

4 Broseta PONT, Manuel. Manual de derecho mercantil, 9. ${ }^{a}$ ed. Madrid: Tecnos, 1991, p. 287.

5 Ibidem.

6 Antolisel, Francesco. Manuale di diritto penale. Leggi complementari, 9. a ed. a cargo de Luigi Conti. Milán: Giuffré, 1994, p. 73; Faraldo Cabana, Patricia. Los delitos societarios. Valencia: Tirant Lo Blanch, 1996, p. 262. 
se consigne en el acta su oposición. Si ella no se consigna en el acta, solicitará que se adicione al acta, según lo antes indicado [...]". No existirán, pues, mayores obstáculos de interpretación legal para imputar responsabilidad mercantil por la intervención en la adopción colectiva de un acuerdo en la sociedad. Los problemas que podrían advertirse serán, en todo caso, de índole probatoria, en tanto que tiene que demostrarse que el comportamiento del administrador ha obedecido a dolo, abuso de facultades o negli-

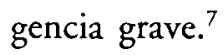

4. Trasladar al campo del derecho penal, y discutir en dicha sede la cuestión anteriormente planteada de la responsabilidad en que incurren los administradores por participar en la aprobación de un acuerdo antijurídico, presupone tomar postura sobre una serie de aspectos que conviene estructurar con arreglo a la metodología propuesta por Suárez González: ${ }^{8}$ ¿cuándo se responde por participar en la toma de decisiones de un órgano colegiado?; ¿Cómo se responde una vez adoptado el acuerdo?; y, ¿cómo se determina la responsabilidad individual por la participación en la adopción del acuerdo? En otras palabras, reconociendo que con frecuencia la realidad demuestra que la intervención de los directores de las sociedades en el hecho delictivo se limita a su intervención en la adopción del acuerdo que lo origina, ${ }^{9}$ habrá que responder las siguientes interrogantes: ¿cuándo y a partir de qué momento resulta penalmente relevante la participación, activa u omisiva, en la adopción de un acuerdo social?; ‘a título de qué (autor directo, mediato, instigador, cooperador necesario, cómplice) se responde?; y, ¿cuál es el fundamento de dicha responsabilidad?

\section{Cuestiones previas: responsabilidad societaria vs. responsabili- dad penal}

1. La LGS no solo establece las causales de responsabilidad mercantil para los administradores de las sociedades, sino que sus preceptos configuran un

7 Al respecto, BEAUMONT, Ricardo. Comentarios a la nueva ley general de sociedades. Lima: Gaceta Jurídica, 1998, p. 381.

- SuÁrez González, Carlos. "Participación en las decisiones del consejo de administración de una sociedad y responsabilidad penal». CDI, 1994, Madrid, pp. 47 y ss. Asumen este planteamiento metodológico, entre otros, DeL ROSAL BLASCO, Bernardo. Los delitos societarios en el Código Penal de 1995. Valencia: Tirant lo Blanch, 1998, pp. 68 y ss; MARTÍNEZ-BujÁN Pérez, Carlos. Derecho penal económico, PE. Valencia: Tirant lo Blanch, 1999, pp. 184 y ss; y NúÑEZ CASTAÑO, María Elena. Responsabilidad penal en la empresa. Valencia: Tirant lo Blanch, 2000, pp. 154 y ss.

9 De la misma opinión, MUÑOz CONDE, Francisco. "¿Dominio de la voluntad en virtud de aparatos de poder organizados en organizaciones "no desvinculadas del Derecho"?». $R P$, n. ${ }^{\circ} 6,2000$, p.113. 
marco genérico a partir del cual diferenciar comportamientos propios del cargo y comportamientos ajenos a dicho rol societario. Prevé, además, las medidas que por el incumplimiento de sus funciones se le puede imponer. De manera gráfica, al anteriormente trascrito artículo 177 LGS cabe añadir, por un lado, el artículo 171 LGS, que señala que "Los directores desempeñan el cargo con la diligencia de un ordenado comerciante y de un representante leal $[\ldots]$ »y, por otro lado, el artículo 180 LGS:

Los directores no pueden adoptar acuerdos que no cautelen el interés social sino sus propios intereses o los de terceros relacionados, ni usar en beneficio propio o de terceros relacionados las oportunidades comerciales o de negocios de que tuvieran conocimiento en razón de su cargo. [...] El director que en cualquier asunto tenga interés en contrario al de la sociedad debe manifestarlo y abstenerse de participar en la deliberación y resolución concerniente a dicho asunto. El director que contravenga las disposiciones de este artículo es responsable de los daños y perjuicios que cause a la sociedad y puede ser removido por el directorio o por la junta general a propuesta de cualquier accionista o director [...].

2. El carácter subsidiario del derecho penal obliga a descartar la tipicidad penal de aquellos comportamientos que no constituyan, siquiera, infracciones mercantiles. La razón material viene dada por la ausencia de afectación de bien jurídico alguno o, en caso que esta se dé, por su adecuación social. Se ha de prever, no obstante, una excepción, referida a los casos en los que aquello que ha de ser valorado y enjuiciado es el «efectivo comportamiento y la efectiva voluntad del sujetom. ${ }^{10}$ Expresado con otras palabras, los actos concluyentes que realiza el director antes o durante la adopción colectiva del acuerdo ilícito pueden indicar que ha contribuido a la aprobación de este, con independencia de que haya participado en la votación, y con independencia, también, del contenido de su voto. Dicho con un ejemplo, aquel que, gracias al lobby o a la influencia que ejerce sobre los demás miembros del directorio, ha conseguido que estos voten a favor del acuerdo, ha de ser hecho penalmente responsable, aun cuando él haya votado en contra, en blanco, se haya abstenido o no haya asistido a la sesión. Puede suceder incluso que, con anterioridad a la deliberación, haya manifestado abiertamente su deseo de apoyar la moción sobre el acuerdo antijurídico y que lo defendería en la deliberación, pero, llegado el momento, vote en contra, en blanco, se abstenga o no asista a la sesión al no necesitarse su voto para la aprobación de la moción. Se trata, pues, de una actitud conscientemente

10 ANTOlisel, op. cit., pp. 73 y 74; SUÁREZ GONZÁLEZ, op. cit., pp. 53-54; MARTINEZ-BUjÁN PÉREZ, op. cit., pp. 185 y 186; RODRIGUEz MOURULLO, Gonzalo. "Consideraciones político-criminales sobre los delitos societarios». ADPCP, 1984, p. 687. 
favorecedora ${ }^{11} \mathrm{o}$, incluso, de una conducta imprudente y causalmente necesaria para la aprobación del acuerdo antijurídico.

En este sentido, es importante tomar en cuenta que la votación es la exteriorización de una voluntad que, como toda manifestación humana, puede aparecer en el mundo real solapando los verdaderos conocimientos y la verdadera intención de su autor: se puede mentir. En tal medida, no hay razón alguna para que se exonere automáticamente de responsabilidad penal a quien ha votado en contra del acuerdo, puesto que, desde el punto de vista del derecho penal, habrá que asegurarse que la votación coincida con su voluntad. ${ }^{12}$ En buena cuenta, la valoración de las formalidades que rodean al derecho mercantil debe ceder paso a la valoración de lo material, que es lo penalmente relevante.

3. De esto se deriva que la mera formalidad de registrar en actas la oposición al acuerdo colectivo, o que la no participación en la sesión donde se aprueba, no excluye, per se, de responsabilidad penal. ${ }^{13}$ Si se asume esta idea, y se recuerda aquello del derecho penal como ultima ratio, se advertirá la paradoja de que un mismo acto (ser miembro del directorio y consignar en actas la oposición al acuerdo según lo dispuesto en el artículo 170 LGS) podría fundamentar responsabilidad penal cuando, en términos mercantiles y según la normativa mercantil, es lícito. El sentido común, empero, indica que si el administrador incurre en responsabilidad penal es porque su comportamiento es ya ilícito para el derecho mercantil, aun cuando haya consignado su oposición al acuerdo en actas. La paradoja, ahora, no es tal, pues la simple oposición al acuerdo resulta insuficiente para que el administrador salve su responsabilidad; lo lógico y exigible es que impugne el acuerdo para evitar el daño a la sociedad o sus accionistas o partícipes. ${ }^{14}$

$"$ Di Amato, Astolfo. Diritto penale dell'impresa, 4.a ed. Milano: Giuffré, 1999, pp. 124 y ss; CONTI, Luigi. Disposizioni penali in materia di società e di consorzi, 3. a ed. Roma: Zanichelli, 1988, p. 21; RODRIGUez MOURUllo, op. cit., p. 687; ANTOLISE, op. cit., pp. 73-74; SUÁrez González, op. cit., pp. 53-54; FARALDO CABANA, op. cit., p. 266; y MARTínezBUIÁN PÉREZ, op. cit., p. 185.

12 Ya la doctrina había llamado la atención sobre lo poco convincente que resulta que la simple ausencia (o el votar en contra, en blanco o abstenerse de votar) deba exonerar de responsabilidad penal, ya que así podrán eximirse aquellos sujetos cuya participación haya sido relevante para la adopción del acuerdo, pero no hayan asistido a la reunión o salvaran su voto. Véase, TERradlllos Basoco, Juan. Derecho Penal de la Empresa. Madrid: Trotta, 1995, p. 43; FARAldo CABANA, op. cit., p. 267; RoDRícuez MOURUllo, op. cit., p. 687.

13 En el mismo sentido, VALle MUÑIZ, José Manuel. «De los delitos societarios». En: QUINTERo Olivares, Gonzalo (dir.) y Fermín MORAles PRATS (coord.) Comentarios a la Parte Especial del Derecho Penal, 2. ${ }^{\text {a }}$ ed. Pamplona: Aranzadi, 1999, p. 1308.

14 Así, GOMEZ-Benitez, José Manuel. Curso de Derecho penal de los negocios a través de casos. Reflexiones sobre el desorden legal. Madrid: Colex, 2001, p. 98. 
En esta línea de pensamiento, la oposición expresa del administrador no debe ser meramente formal, sino que ha de demostrar la ausencia de dolo y de negligencia, ${ }^{15}$ en el sentido del criterio del «efectivo comportamiento y efectiva voluntad».

4. La determinación de la responsabilidad penal de los que intervienen en la adopción de acuerdos colectivos en una sociedad presupone también determinar las esferas de competencia de los intervinientes. ${ }^{16}$ Ello es de especial importancia de cara a la responsabilidad penal en la que se puede incurrir por omitir impugnar el acuerdo ilícito. ${ }^{17}$ Por otro lado, adquiere también relevancia el hecho de que, a diferencia de los supuestos tradicionales de codelincuencia - en los que la actuación conjunta normalmente hubiera podido realizarse también individualmente-, en las hipótesis de adopción colectiva de acuerdos ello no es dable. Pues cada uno de los miembros del órgano colegiado, individualmente considerados, no tiene ni la capacidad ni la competencia para adoptar por sí solo el acuerdo. ${ }^{18}$ Esta situación genera, a su vez, que se presenten casos de coautoría imprudente. ${ }^{19}$ Idea, esta, que viene refrendada porque el deber que se infringe en estos supuestos es un deber cuyo ejercicio individual es materialmente imposible. Por el contrario, es un colectivo de personas (directorio) el competente para cumplirlo o infringirlo.

\section{El rechazo del delito colegial}

1. Los intentos por responsabilizar penalmente a los miembros de los órganos colegiados, con motivo de su participación en la adopción de acuerdos

15 Ibidem.

16 MEIER, Berndt-Dieter. "Verbraucherschutz durch Strafrecht? Überlegungen zur strafrechtlichen Produkthaftung nach der "Lederspray" -Entscheidung des BGH», NIW, 1982, p. 3198; VOLK, Klaus. "Criminalitá economica: problemi criminologici, políticocriminali e dommatici». En: Sistema penale e criminalitá economica. Napoli: Edizione Scientifiche Italiane, 1998, pp. 47 y ss.; PEDRaZzI, Cesare. «Profili problematici del diritto penale d'impresa». Rivista trimestrale di diritto penale dell'economia, I, 1988, pp. 129 y ss.; García Cavero, Percy Derecho Penal económico, Parte General. Lima: Ara Editores, 2003, p. 352 s.; MEINI MÉNDEZ, Iván. "Responsabilidad penal de los órganos de dirección de la empresa por comportamientos omisivos. El deber de garante del empresario frente a los hechos cometidos por sus subordinados". Derecho PUCP n. 52,2000 , pp. 883 y ss.

17 En detalle, véase infra IV. D. RODRIGUEZ MONTAÑÉS, op. cit., p. 174.

19 También: WE!ßER, Bettina. Kausalitäts- und Täterschaftsprobleme bei der strafrechtichen Würdigung pflichtwidriger Kollegialentscheidungen. Berlin: Duncker \& Humblot, 1997. p. 144 . 
ilícitos, dieron lugar, en la doctrina jurídico-penal italiana, a la concepción del delito colegial (reato collegiale). Los antecedentes de esta categoría jurídica se remontan al articulo 149 del Código de Comercio Italiano de 1882, que establecía que "la responsabilidad por los actos y las omisiones en las sociedades que tengan varios administradores, no se extenderá al administrador exento de culpa que haya hecho constar sin demora su disentimiento en el libro de actas de las sesiones y que lo haya comunicado por escrito a los auditores de cuentas». Al amparo del mismo, Bonelli concluyó que se era responsable, también penalmente, de las decisiones adoptadas en un órgano colegiado a menos que se haya actuado conforme al artículo 149 del mencionado Código de Comercio. Es decir, haciendo constar sin demora el disentimiento en el libro de actas de las sesiones y que se haya comunicado por escrito a los auditores de cuentas. Por su parte, Sardegna, a propósito de la bancarrota, sostuvo que, en materia penal, se debían aplicar los mismos principios que inspiran la responsabilidad civil de los administradores; en otras palabras, propuso correr traslado de los criterios de responsabilidad colectiva y solidaria que operan en sede mercantil al derecho penal. ${ }^{20}$

2. Pese a todo, se atribuye a Rende la concreción del delito colegial. ${ }^{21}$ Este autor se refirió al reato collegiale como aquel que es realizado, no por personas que se unen para cometer el delito, sino por quienes, estando ya constituidas por ley en órganos colegiados de una persona jurídica, pública o privada, cometen delitos en el ejercicio de sus funciones y, como tales, responden a título de coautores. De acuerdo con esta definición, quedaban al margen de la categoría de delito colegial los actos que fueran ajenos a las funciones del órgano colegiado; y ello con independencia de que hubieran sido cometidos por sus miembros con ocasión de hallarse reunidos. Quedaban, igualmente, fuera del alcance de tal definición, los actos que no exigían las funciones del órgano colegiado del modo previsto por la ley. ${ }^{22}$ Todo esto permitió que sea calificado como un delito plurisubjetivo o de concurso necesario. ${ }^{23} \mathrm{Si}$ a todo esto se le añade que el delito colegial presuponía como requisito la presencia del número mínimo de personas para formar el quórum que permitiese adoptar válidamente el acuerdo colectivo, ${ }^{24}$ resulta

20 Cfr. ANTOLISEI, op. cit., pp. 74 y 55.

2l Así, ANTOlisel, op. cit., p. 75; TeRradillos BASOCO, Juan. Delitos societarios. El derecho penal en las sociedades mercantiles a la luz de nuestra adhesión a la CEE. Madrid: Akal, 1987, p. 61; FARALDO CABANA, op. cit., p. 263; SUÁrEZ GONZÁlEZ, op. cit., p. 45, cita n. ${ }^{\circ} 11$; Martínez-Buján Pérez, op. cit., p. 183; Pérez CePedA, Ana Isabel. La responsabilidad de los administradores de sociedades. Criterios de atribución. Barcelona: Cedecs, 1997, p. 283. ANTOLISEl, op. cit., p. 76.

23 En tal sentido, CONTI, op. cit., p. 17; DI AMATO, op. cit., p. 124.

24 Di amato, op. cit., p. 123; Faraldo Cabana, op. cit, p. 264. 
relativamente fácil apreciar la similitud que guardaba, en orden a sus presupuestos y naturaleza, con la responsabilidad mercantil de la cual emana.

3. Las críticas que, en su momento, se formularon contra el delito colegial, llevaron a que sea rechazado mayoritariamente. ${ }^{25}$ En primer lugar, salta a la vista que, si bien se trataba de una construcción válida para el derecho privado, esta no podía ser traspasada automáticamente al derecho penal, amén del principio de responsabilidad penal individual. ${ }^{26}$ En segundo lugar, desde un punto de vista político-criminal, no existe razón alguna para mantenerlo como delito autónomo, ya que la actuación colegiada no tiene un papel constitutivo en las conductas que pretendía regular. Más bien, se trata de una conducta eventual y accesoria frente a la cual no hay necesidad de realizar una tipificación expresa, y es la prueba más clara de este postulado su ausencia en el derecho comparado. ${ }^{27}$ La solución que se impone pasa entonces por acudir a las reglas de autoría y participación, pues no todos los miembros del órgano colegiado van a responder siempre, y aunque así fuera, no todos tienen que hacerlo de la misma manera: unos pueden responder como autores, otros como partícipes. ${ }^{28}$ En tercer lugar, como se ha sostenido en doctrina, ${ }^{29}$ en la construcción del delito colegial se parte erróneamente de que se aplica a supuestos de órganos colegiados, sin tener en cuenta que los comportamientos sobre los que se proyecta pueden ser realizados también por una sola persona (por ejemplo, sociedad unipersonal), situación que, por lo demás, no resulta poco frecuente. $\mathrm{Y}$, en cuarto lugar, desde un punto de vista dogmático-sistemático carece de sentido hablar de delito colegial, ya que es nula su utilidad en la construcción y clasificación de diversas instituciones jurídico-penales, e irrelevante el nomen. ${ }^{30}$

${ }_{25}$ Véase solo las múltiples referencias bibliográficas en PÉREz CePEDA, op. cit., p. 284, cita n. ${ }^{\circ} 830$.

zo En este sentido, Mantovani, Ferrando. Diritto Penale, Parte Generale, 3. a ed. Padua: Cedam, 1992, pp. 151 y ss.; CONTI, op. cit., p. 19; TeRRADILLOS BASOCO, op. cit., p. 62; Faraldo Cabana, op. cit., p. 264; Rodrícuez MOURUllo, op. cit., p. 687; MartínezBuján Pérez, op. cit., p. 183; SuÁrez GonzÁlez, op. cit., pp. 46 y ss.; Pérez Cepeda, op. cit., pp. 285-287; MuÑoz CONDE, Francisco. Manual de Derecho Penal, PE, 13.a ed. Valencia: Tirant lo Blanch, 2001, p. 458; CARACCIOLI, Ivo. Manuale di Diritto Penale, Parte Generale. Padova: Cedam, 1998, pp. 132-133; PAGLIARO, Antonio. Principi di Diritto Penale, Parte Generale, 7.a ed. Milán: Giuffrè, 2000, pp. 164-165; y PaDOVANI, Tullio. Diritto Penale, 5. ed. Milán: Giuffrè, 1999, p. 119-120.

TeRradillos BAsOCo, op. cit., p. 61.

2 Asi también, TerRadillos Basoco, op. cit., p. 61; Di AMATo, op. cit., p. 124; ANTOLISEl, op. cit., p. 77; Rodríguez MOURULlLo, op. cit, p. 687; FARALDO CABANA, op. cit., pp. 264267; MuÑoz CONDE, Manual de Derecho..., p. 458; NúÑez CASTAÑo, op. cit., p. 152. ANTOlisel, op. cit., p. 77; CONTI, op. cit., p. 18; SUÁrez GONZÁlez, op. cit., p. 46.

30 ContI, op. cit., p. 18; Terradillos Basoco, op. cit., p. 61; Faraldo Cabana, op. cit., p. 264. 
4. Con todo, más allá de las criticas que la doctrina enarboló, lo importante - y a lo que apuntaba en esencia el reato collegiale- es formular alternativas para solventar los casos del miembro disidente por ausencia ${ }^{31} \mathrm{y}$, fundamentalmente, para superar los problemas probatorios en los delitos cometidos por medio de un consejo de administración. ${ }^{32}$

\section{Supuestos en que se responde penalmente por intervenir en la adopción colectiva de un acuerdo ilícito en una sociedad}

1. Con cargo a demostrarlo más adelante, ${ }^{33}$ la participación en la votación y posterior adopción de un acuerdo ilícito no constituye delito de por sí, sino que el delito se da recién cuando el acuerdo se ejecuta. Lo normal, habida cuenta del principio de jerarquía y de la división del trabajo que inspira la organización empresarial, es que el acuerdo se ejecute no por los directores que lo aprueban, sino por trabajadores subordinados a ellos. En la medida en que esto es así, es decir, en la medida en que el director interviene en el iter criminis únicamente mediante la emisión de su voto, se habrá que ubicar en dicho comportamiento la razón que permita afirmar que la ejecución del acuerdo que llevan a cabo otras personas aparece como hecho suyo, o como hecho también suyo, ${ }^{34} \mathrm{y}$ con ello afirmar su responsabilidad penal. Todo esto, claro está, a no ser que quien interviene en la votación participe, además, en la ejecución del acuerdo.

2. Así las cosas, se plantea la necesidad de indagar, por un lado, la relación entre el comportamiento de cada director y el acuerdo que se aprueba (por ejemplo, el votar a favor, en contra, en blanco, etcétera, con el acuerdo ilícito aprobado) y, por otro lado, la relación entre la ejecución del acuerdo y las lesiones a bienes jurídicos penalmente protegidos que se realizan con tal ejecución ${ }^{35}$ (por ejemplo, la introducción en el mercado de un producto peligroso para la salud con las lesiones a la salud que su consumo reporta, o la venta de un inmueble subvaluado con el perjuicio patrimonial a la sociedad dueña del local). Lo segundo, es decir, la relación entre el acuerdo ya aprobado y las lesiones causadas, no es aquí objeto de análisis. Los problemas

31 faraldo Cabana, op. cit., p. 266; Pérez Cepeda, op. cit., p. 283.

* Lo apunta también PÉrEz CePEDA, op. cit., p. 283.

3 Vpease infra $\mathrm{V}$.

34 JaKOBS, Günther. "Responsabilidad penal en supuestos de adopción colectiva de acuerdos". En: MIR, Santiago y Diego M. Luzón (eds.). Responsabilidad penal de las empresas y sus órganos y responsabilidad por el producto. Barcelona: Bosch, 1996, p. 78; RODRÍGUEZ MONTAÑÉs, op. cit., pp. 185-186.

35 HILGENDORF, op. cit., p. 565 
de índole causal que ello puede plantear, al no saberse a ciencia cierta si el resultado puede ser imputado a la ejecución del acuerdo, no son abordados aquí. Parto, pues, en este trabajo, de que el resultado es imputable objetivamente a la ejecución del acuerdo colectivo. Así, me interesa únicamente la relación entre la intervención en la adopción colectiva de un acuerdo ilícito y el resultado lesivo que se produce a consecuencia de su ejecución. ${ }^{36}$ Esta cuestión tiene que abordarse desde la óptica de la teoría de la imputación objetiva del resultado. ${ }^{37}$

\section{A. Votación nominal no secreta}

\section{Votación nominal simultánea y no secreta}

A diferencia de los que votan en contra del acuerdo, solo aquellos que votan a favor participan en la formación de la mayoría necesaria para la adopción del acuerdo. Luego, solo estos crean o incrementan el riesgo prohibido. ${ }^{38}$ La excepción a esta regla viene dada por el criterio, anteriormente apuntado, de la «efectiva voluntad y efectivo comportamiento".

2. Votación nominal no simultánea y no secreta

Lo importante aquí es la oportunidad en que se emite el voto. Basándose en este criterio, es conveniente diferenciar los casos en que el voto es emitido antes de alcanzarse la mayoría necesaria para la aprobación del acuerdo, de aquellas otras hipótesis en las que el voto es emitido con posterioridad.

a) Si se ha votado a favor con antelación a obtenerse la mayoría necesaria para la aprobación del acuerdo, la imputación objetiva queda justificada por haberse creado un riesgo no permitido. La responsabilidad penal no se deriva de participar en la formación de la voluntad de la sociedad, sino porque el sujeto ha contribuido a conformar la mayoría requerida para la aprobación de un acuerdo ilícito. ${ }^{39}$

b) Los supuestos en que se vota a favor del acuerdo antijurídico, después de alcanzado un número de votos que aseguran la mayoría requerida para

3 Siguen esta metodología, JAKOBS, op. cit.; Cerezo Mir, José. Curso de Derecho penal español, Parte general, Il, Teoría jurídica del delito, 6. ${ }^{\mathrm{a}}$ ed. Madrid: Tecnos, 1998, pp. 52 y ss., en especial, p. 57, con cita n. ${ }^{\circ} 24$; RODŔ́GUEZ MONTAÑES, op. cit., p. 176-184. Sin problemas, Gimbernat, op. cit., pp. 363 y ss.

37 En este sentido, Jakobs, op. cit., p. 88; Martínez-Buján Pérez, op. cit., p. 184; Pérez CEPEDA, op. cit., pp. 279 y ss., 282, 291 y ss.; EIDAM, Gerd. Straftäter Unternehmen, 2. Aufl. Múnich: Bech, 2000, pp. 259 y ss.; MEIER, op. cit., p. 3198; Kuhlen, op. cit., p. 1145; HILGENDORF, op. cit., p. 561.

33 HILGENDORF, op. cit., p. 565.

39 En el mismo sentido, Martínez-Buján Pérez, op. cit., p. 185; Del rosal Blasco, op. cit., p. 69. 
su aprobación, han posibilitado diversos pronunciamientos doctrinales que conducen a la misma respuesta.

Jakobs califica estos supuestos como supuestos de "conformidad formal» que son, en definitiva, problemas de "resultados sobrecondicionados" o "hipercondicionados". ${ }^{40}$ Se trataría, según este autor, de hipótesis en las que el resultado se encuentra sobrecondicionado en el sentido de que, omitiendo una conducta de las que concurren, el resultado se produciría igualmente. ${ }^{41}$ Partiendo del hecho de que la votación no es, en sí misma, exteriorización (ejecución del hecho), sino que prepara internamente una conducta negocial que se ejecutará posteriormente y que recién entonces se exteriorizará (es, pues, un mero acto preparatorio), e independientemente del momento en que la votación se lleve a cabo, lo decisivo para la infracción de la norma penal es la conducta con la cual se ejecuta el acuerdo ilícito por quien constata la mayoría o bien, generalmente, por el gestor del negocio competente en el ámbito de que se trate. ${ }^{42} \mathrm{De}$ ahí se sigue, según este autor, que la conducta negocial preparada mediante la emisión de los votos se realiza en el acto de ejecución del acuerdo, o lo que es lo mismo, simultáneamente para todos los que dieron su conformidad. Esto significa que todos los que votaron a favor responderán penalmente, siendo irrelevante cuándo emitieron su voto. Lo decisivo es, únicamente, el momento de la exteriorización (ejecución del acuerdo) en que se vulnera la norma, y en ese momento coexisten dos o más condiciones que son, independientemente una de la otra, suficientes para la consecución del resultado. ${ }^{43}$

Un razonamiento similar sigue Jakobs para los denominados supuestos de «conformidad informal», esto es, aquellos casos en que el ausente en la votación comunica luego su conformidad con el resultado. Aquí, lo decisivo es el refuerzo de las razones a favor de la ejecución del acuerdo ilícito, y no tanto la superación de los obstáculos; es indiferente si esto puede describirse como aumento de las razones preexistentes o como superación de las razones en contra. "Es irrelevante - sostiene este autor- que las razones preexistentes sean de por sí suficientes, si se mejoran o aumenta: en el

\footnotetext{
JaKOBS, op. cit., pp. 79-80; y también en su Derecho Penal, Parte Ceneral. Fundamentos y teoría de la imputación, 2. ${ }^{a}$ ed. Madrid: Marcial Pons, 1995, ap. 7, n.m. 83.'.

41 JAKOBS, Derecho penal..., ap. 7, n.m. 83. a; y también, «Responsabilidad penal..., pp. 7980. Se trata de supuestos de causalidad distintos a los de causalidad cumulativa, en tanto que en estos (causalidad cumulativa) confluyen varios cursos causales que, por sí solos, no son suficientes para producir el resultado lesivo, y respecto de cuya confluencia no existe acuerdo previo. Véase GIMBERnAT, op. cit., p. 364, cita n. ${ }^{\circ} 29$; REYES AlvARADO, Yesid. Imputación objetiva. Santa Fe de Bogotá: Temis, 1995, pp. 381 y ss.; MIR PUIG, Santiago. Derecho Penal. Parte General, 5. ${ }^{\mathrm{a}}$ ed. Barcelona: PPU, 1998, L. 10/27 y ss. 
hecho se exteriorizan todas las razonesm. ${ }^{44}$ De acuerdo con esto, quien comunica informalmente su conformidad con el acuerdo ilícito con posterioridad a su aprobación neutraliza igualmente un obstáculo y, aun cuando el autor lo hubiere superado por su cuenta o por cuenta de otro, se debe aceptar que interviene también quien psíquicamente allana la situación. ${ }^{45}$

Otro sector doctrinal argumenta la responsabilidad penal de quienes votan a favor después de haberse alcanzado la mayoría necesaria para la aprobación del acuerdo antijurídico bajo el entendido de que con el voto se ha coadyuvado, objetivamente, a configurar la voluntad general del órgano colegial, con lo que se forma parte del acuerdo ilícito adoptado. ${ }^{46}$

Ambas posiciones llegan a los mismos resultados. La postura que se tome ha de responder al planteamiento de si se puede imputar objetivamente los efectos de la ejecución del acuerdo a quien votó en favor de él cuando, sin su participación, el acuerdo antijurídico se hubiera aprobado y ejecutado igualmente. Se podría pensar que cuando se ejecuta el acuerdo ilícito todos los votos a favor aparecen como suficientes para el resultado, sin importar si se producen antes o después de alcanzada la mayoría. Todas las conductas de votar a favor del acuerdo antijurídico deberían, entonces, ser reprobadas por el ordenamiento jurídico-penal, ya que, así considerados, todos y cada uno de los votos a favor del acuerdo antijurídico ejecutado han creado un riesgo típico no tolerado. No obstante, la relación de causalidad, al menos desde la teoría de la conditio sine qua non, no se da. ${ }^{47} \mathrm{~A}$ lo que hay que sumar que el criterio de la creación o incremento del riesgo conduce, en este caso, a resultados insatisfactorios. Pues los votos a favor emitidos con posterioridad al momento de haberse alcanzado la mayoría necesaria para su aprobación, no crean un riesgo típico ni aumentan uno ya existente. La razón es que el riesgo fue creado anteriormente por quienes conformaron con sus votos la mayoría, y porque los efectos del acuerdo serán siempre los mismos, con independencia de por cuántos votos se haya superado la mayoría exigida. Por eso, en las hipótesis de resultados sobrecondicionados, al igual que en otros supuestos de cursos alternativos ajustados a derecho, habrá que prescindir del criterio del incremento del riesgo y acudir al de la

4 Ibidem, p. 88 y 89 . Hay que tener presente que, acorde con ello, la conducta del partícipe debe valorarse desde el punto de vista del Derecho, pues entonces la votación informal cobra relevancia ya que en la ejecución del acuerdo se exteriorizan todas las razones que se tienen en cuenta para ello. Se adhiere a este planteamiento, PÉrEz CEPEDA, op. cit., p. 301 y 302.

45 JAKOBS, "Responsabilidad penal..., p. 87.

- Suárez González, op. cit., p. 48 y ss.; Del rosal Blasco, op. cit., p. 69; martínez-Buián PÉREZ, op. cit., p. 185.

47 En este sentido, EIDAM, op. cit., p. 261. 
realización del peligro inherente a la acción y al del fin de protección de la norma. ${ }^{48}$ En virtud de ello, se podrá imputar objetivamente el resultado a quienes votan a favor del acuerdo antijurídico después de que este se haya aprobado. Así, el distinguir entre una votación simultánea y una no simultánea pierde sentido, porque lo relevante es valorar cómo el sujeto, con el ejercicio que hace de su derecho a votar, contribuye, en términos normativos, a la aprobación del acuerdo ilícito.

\section{B. Votación secreta}

1. En un plano estrictamente teórico estos casos no tienen por qué tratarse de manera distinta a los anteriormente estudiados, toda vez que los problemas que presentan son de índole probatorio. En otras palabras, la responsabilidad penal de aquellos que en una votación secreta emitan sus votos a favor del acuerdo ilícito simultáneamente, antes o después de alcanzarse la mayoría necesaria para su aprobación, se encuentra ya discutida y afirmada. Pero lo difícil - por no decir imposible - será identificar cuáles de los participantes en la votación han votado a favor y cuáles no. La situación se solucionará fácilmente cuando la decisión colegiada se haya aprobado por unanimidad, al poder imputarse los efectos del acuerdo a todos los participantes de la votación, ${ }^{50}$ y estos serán considerados coautores, dolosos o imprudentes. Pero bastará que un solo miembro del órgano colegiado no lo haya hecho para que, in dubio pro reo, no se pueda imputar responsabilidad penal a ninguno de los directores, a no ser que se disponga de otros medios para averiguar el contenido de los votos. ${ }^{51}$

4. Luzon PeÑa, Diego Manuel. Curso de Derecho Penal, Parte general, I. Madi 'd: Universitas, 1996, pp. 382-384. Para el caso de los acuerdos en órganos colegiados, de la misma opinión, RODRÍGUEZ MONTAÑES, op. cit., p. 184.

4 El artículo 170 LGS prescribe que aLas deliberaciones y acuerdos del directorio deben ser consignadas, por cualquier medio, en actas que se recogerán en un libro, en hojas sueltas o en otra forma que permita la ley $y$, excepcionalmente, conforme al artículo 136. Las actas deben expresar, si hubiera habido sesión: la fecha, hora y lugar de celebración y el nombre de los concurrentes; de no haber habido sesión la forma $y$ circunstancias en que se adoptaron el o los acuerdos; $y$, en todo caso, los asuntos tratados, las resoluciones adoptadas y el número de votos emitidos, asi como las constancias que quieran dejar los directores". Es decir, no se regula la obligación de hacer constar en actas el contenido de los votos por lo que, por el contrario, las votaciones secretas son supuestos perfectamente viables en nuestro sistema jurídico, más aún cuando el artículo 188, num. 3 LGS regula las "sesiones reservadas", a las que concurren solamente los miembros del directorio $y$, una vez culminada, se dicta al secretario del directorio el resumen o sumilla de los acuerdos que se hayan adoptado en ella. Cfr. BEAUMONT, op. cit., p. 395.

30 En el mismo sentido, Weißer, op. cit., pp. 169, 184; Pérez CePeDA, op. cit., p. 303; Martínez-Buján Pérez, op. cit., p. 186

51 En el mismo sentido, WEIßER, op. cit., pp. 184 y ss. 
2. La solución contraria de hacer responsables a todos los miembros del directorio choca frontalmente con el principio de culpabilidad y de responsabilidad por el hecho propio. Pero lo cierto es que quienes quieran aprobar un acuerdo ilícito, y evitar ser sancionados penalmente, tienen aquí un camino fiable, al poder acordarse que la votación será secreta y que solo uno, o la minoría, votará en contra, y consignarlo así en actas. La solución pasaría por exigir que los directores que votan en contra, y que efectivamente pretendan salvar su responsabilidad, dejen constancia en actas de que se oponen a la forma secreta en que se lleva a cabo la votación, y que impugnen el acuerdo o hagan lo posible para evitar su ejecución.

\section{Supuestos en que se vota en contra, en blanco, se abstiene o no se concurre a la votación}

1. En principio, parecería no haber obstáculo para reconocer que quien emite su voto en contra de la adopción del acuerdo antijurídico, o el que vota en blanco o se abstiene de votar, y con mayor razón quien no participa en la votación, no tiene por qué soportar la imputación de responsabilidad penal, más aún cuando nadie puede tener la obligación de impedir el resultado de la votación. Y, en efecto, en principio, es así, en la medida en que cuando se vota en contra o se abstiene de votar no hay causalidad. ${ }^{52} \mathrm{La}$ excepción, una vez más, la constituye "la efectiva voluntad y el efectivo comportamientom. ${ }^{53}$

\section{Supuestos de colaboración disidente}

1. ¿Qué pasa con el miembro del órgano colegiado que se manifiesta en contra de la aprobación del acuerdo antijurídico, pero su presencia en el acto de votación ha permitido la conformación del quórum necesario para proceder a la deliberación, y posterior aprobación, del acuerdo ilícito? En otras palabras, ¿es relevante para el Derecho Penal que se haya podido impedir la aprobación del acuerdo antijurídico mediante la inasistencia a la sesión del órgano colegiado?

2. Sí es claro que no es dable imputar responsabilidad penal por el mero hecho de haber participado en la votación, pues tal es un derecho y un deber consustancial del cargo de director. Luego, y sin perjuicio de reconocer la causalidad del comportamiento del disidente - por participar, no por disidir - en el proceso de votación, no hay base lógica para afirmar que

52 EIDAM, op. cit, p. 259; WeIßER, op. cit., pp. 172 y ss.

5 Véase supra ll y el ejemplo ahí expuesto. 
por ello el disidente opte por el contenido final de la decisión colegiada, sino que, simplemente, acepta el proceso de formación de opinión. ${ }^{54}$ En todo caso, si se llegara a imputar responsabilidad penal tendría que ser por no haber impedido la adopción de un acuerdo, lo que sería, entonces, una responsabilidad a título de omisión. Al respecto, dos observaciones. La primera: en el ordenamiento jurídico-penal peruano no existe un delito de omisión pura que reprima al director por no intentar evitar la adopción de un acuerdo. Luego, amén del principio de legalidad, la mera participación en la votación, en los términos expuestos, no puede desencadenar responsabilidad penal alguna. La segunda: este caso tampoco puede ser subsumible en un supuesto de comisión por omisión, en tanto que el director no tiene un deber de garante de evitar la votación. No solo porque el estar presente en ella y posibilitar la conformación del quórum en modo alguno equivale a la aceptación del resultado de la votación, sino, fundamentalmente, porque, como se ha dicho, el director tiene el derecho y la obligación de estar presente, participar y votar, o de abstenerse. ${ }^{55}$

3. Sin embargo, de ahí a afirmar que nadie tiene el deber de garante de que los otros se comporten de manera correcta y de que no cometan delitos, como procede un sector cualificado de la doctrina, ${ }^{56}$ hay un paso que personalmente no suscribo. Muchas veces, sobre todo en los casos de relaciones estructuradas con arreglo al principio de jerarquía y división del trabajo, en donde el superior tiene determinados deberes de vigilancia frente a su subordinado, cabe afirmar que al primero le compete un deber de garante en el sentido de que el segundo no realice acciones inadecuadas en el desempeño de sus funciones y que no lesione bienes jurídicos protegidos. ${ }^{57}$ En esta línea, no se pretende afirmar que exista un deber de garante que obligue al director a evitar la aprobación del acuerdo antijurídico, o lo que es lo mismo, a garantizar el contenido de la votación; más bien, se quiere admitir la existencia de un deber de garante en virtud del cual se pueda exigir al miembro del órgano colegiado que lleve a cabo todas las acciones posibles para evitar la ejecución del acuerdo ilícito. Sobre la base de ello, la relación contractual que existe entre el director y la sociedad ${ }^{58} y$, de manera específica, el contenido de la normativa mercantil (gráficamente, los artículos

54 JAKOBS, «Responsabilidad penal..., pp. 89 y 90.

55 En el mismo sentido, WeißER, op. cit., p. 209 y ss.

s6 En el mismo sentido, ibidem, pp. 180,184. De otro parecer, SUÁREZ GONZÁLEZ, op. cit., p. 55; Del rosal Blasco, op. cit., p. 71; Martínez-Buján Pérez, op. cit., p. 186.

$\rightarrow$ Otra cosa es que el superior jerárquico responda como autor o partícipe en comisión por omisión, pero, en principio, me parece meridianamente clara la existencia de un deber de garante, cfr. MEINI MENDEZ, op. cit., pp. 883 y ss. y la bibliografía ahí citada.

so En el mismo sentido, SCHMidt-Salzer, op. cit., p. 1310; Weißer, op. cit., p. 167. 
171, 177 y 180 LGS), han de ser considerados fuentes de posiciones de garantes, en la medida en que ambas apuntan a que el miembro del órgano colegiado, que en tanto director de la sociedad, debe salvaguardar los intereses de su representada. ${ }^{59}$ Lo mismo cabe afirmar para aquel director que, teniendo derecho de veto, no lo ejercita. ${ }^{60}$

4. Al margen de todo ello, si el artículo 170 LGS exige al director la obligación de consignar su oposición en la respectiva acta, para exonerarse de responsabilidad civil; ¿se debe entender que el disidente, para librarse de responsabilidad penal, tiene que hacer lo mismo? Entiendo que no, porque en la colaboración disidente sucede lo mismo que en las hipótesis en que se vota en contra del acuerdo ilícito, es decir, lo que al derecho penal le interesa es "el efectivo comportamiento y la efectiva voluntad del sujeto". Dicho con otras palabras, así como quien vota en contra del acuerdo ilícito puede haber manifestado previamente su deseo de apoyarlo - e incluso afirmar que lo defendería en la deliberación- pero no lo hace y, además, consigna en actas su oposición, no queda exonerado de responsabilidad penal por aquello del "efectivo comportamiento y la efectiva voluntad del sujeto", de la misma manera, cuando un director no consigne su oposición en el acta, pese a haber votado en contra, no significa que sea responsable penalmente. $Y$ esto, con independencia de las implicancias mercantiles que ello pueda suscitar. Se tendrá que probar, según lo que exige el principio de presunción de inocencia, que el director efectivamente ha participado en la elaboración del contenido del acuerdo. En suma, el artículo 170 LGS prevé, de cara al derecho penal, una presunción que, como tal, no tiene cabida en el sistema jurídico-penal.

5. Por último, ¿se podría imputar responsabilidad penal al director disidente por el delito de omisión de denuncia del artículo 407 del CP? En dicho precepto, se hace mención a "la comisión de un delito" y a que el sujeto se encuentre obligado por razón de "su profesión o empleo». Respecto a lo primero, conforme se ha adelantado y según lo que se verá adelante, al menos para los acuerdos antijurídicos que requieren de ulterior ejecución, la participación en la votación es participación en un impune acto preparatorio, mientras que la aprobación del acuerdo es ya comienzo de ejecución, es decir, tentativa. De ahí se sigue que cuando el artículo $407 \mathrm{CP}$ exige "la comisión de algún delito", o bien se concluye que la conducta es atípica en lo que al artículo $407 \mathrm{CP}$ respecta, al no existir todavía un delito (habrá un acto preparatorio o tentativa, dependiendo de si el acuerdo se ha

9 El mismo razonamiento se aprecia en VAlLE MUÑIz, op. cit., p. 1308; PÉREz CePEDA, op. cit., pp. 163 y ss.

6) WEIßER, op. cit., pp. 217, 234. 
aprobado o no); o bien, que el artículo $407 \mathrm{CP}$ se refiere no solo a un delito consumado, sino también a tentativas o actos preparatorios punibles, pues sería absurdo esperar a que el delito se encuentre consumado para exigir, recién, a quien conocía que se cometería una infracción penal, que participe de ello a las autoridades. Esta segunda interpretación quedaría refrendada por el hecho de que el delito no es una infracción consumada, sino un acto antijurídico y culpable. De manera que, así como hay delitos consumados, hay también delitos en grado de tentativa.

Respecto a lo segundo, jacaso el ostentar la condición de miembro de un órgano colegiado puede ser la base para afirmar que se tiene la obligación para denunciar lo que ocurra en el seno del mismo? El cargo de director da lugar, como ya se afirmó, a una posición de garante frente a la evitación de la ejecución del acuerdo, pero lo que no se puede afirmar es que se tiene la obligación de denunciar actos preparatorios en tanto que estos son impunes. Cuando se trate de tentativa - en buena cuenta, cuando el acuerdo haya sido aprobado- sí tendrá tal obligación.

\section{E. Votación a favor del acuerdo antijurídico pero este no se aprueba}

1. Piénsese en la siguiente hipótesis: un director de una sociedad, cuyo objeto social consiste en la comercialización de productos alimenticios, propone, con la intención de que se apruebe un acuerdo que lo permita, introducir en el mercado alimentos perjudiciales para la salud, y hace denodados esfuerzos para convencer a los demás miembros del consejo de administración de las bondades de estos. Felizmente para los consumidores, la propuesta es rechazada y, sin importar las razones del por qué se concluyó no aprobarla, lo relevante para el Derecho Penal es que no exi.te acuerdo antijurídico, y luego, no puede haber ejecución. En efecto, si, como se viene insistiendo, la participación (votar a favor) en la adopción de un acuerdo antijurídico no ejecutivo es participación en un hecho preparatorio no punible, a fortiori, la participación (votar a favor) en un acto en el cual no se aprueba acuerdo alguno será también impune. ${ }^{61}$

\section{F. Supuestos en que no se solicita la anulación del acuerdo antijurídico}

1. Se plantea, por último, el caso en que se logra aprobar un acuerdo antijurídico cuyo contenido todos los miembros del directorio conocen. $\mathrm{El}$ único que votó en contra, ¿tiene la obligación de solicitar la anulación del acuerdo para salvar su responsabilidad? Y el director ausente en la votación,

61 Así también, WeIßER, op. cit., p. $206 \mathrm{~s}$. 
¿debe proponer que se anule al acuerdo, aun cuando no exista posibilidad de que este se modifique?

2. Estos son supuestos que nada tienen que ver con el arrepentimiento del que participa en la deliberación y vota a favor del acuerdo ilícito, cuyo tratamiento dogmático tiene que realizarse a la luz de las normas del desistimiento. ${ }^{62}$ Pues bien, siguiendo el mismo razonamiento esbozado con ocasión del estudio de los supuestos de colaboración disidente, ${ }^{63}$ como el comportamiento consiste en una omisión pura - no solicitar la impugnación del acuerdo antijurídico- y como no existe un delito que sancione al que no solicite la anulación de un acuerdo, por imperio del principio de legalidad, no es posible afirmar la existencia de responsabilidad penal. Se tiene, pues, que cuestionar sobre la existencia de un deber de garante que le asiste al miembro del órgano colegiado en cuya virtud tenga que solicitar la anulación del acuerdo $y$, en consecuencia, cuestionarse sobre la posibilidad de que se impute responsabilidad penal a título de comisión por omisión. ${ }^{64}$

3. Así las cosas, resulta obvio que, si se cumplen los requisitos de la comisión por omisión, no habrá ningún problema en afirmar la responsabilidad correspondiente. Sin entrar en detalles, basta con recordar que estos delitos importan la existencia de un deber de garante que obligue al sujeto sobre quien recae, cuando pueda, a evitar la producción de un resultado, además de la aceptación de un criterio de equivalencia valorativa entre la omisión y la acción positiva que describe el correspondiente tipo. Conforme a lo expresado anteriormente, en mi concepto, los administradores de las sociedades ostentan un deber de garante frente a la sociedad y frente a sus accionistas, en virtud del cual tienen que hacer lo posible para impedir la lesión o puesta en peligro de los bienes jurídicos propios de la empresa cuya administración les ha sido confiada. ${ }^{65}$

4. La legislación (artículo 171 LGS) reconoce grosso modo dicha obligación, y obliga a llevar a cabo todos y cada uno de los medios necesarios para evitar que el acuerdo se ejecute. Esto es reconocido también por la doctrina. ${ }^{66}$ En este contexto, resulta válido recordar lo dicho anteriormente, ${ }^{67}$ en el sentido de que la simple oposición al acuerdo resulta insuficiente para

62 En ese sentido, JAKOBS, «Responsabilidad penal..., pp. 91 y ss.

63 Véase supra IV. D.

64 En el mismo sentido, MaRTÍnez-BujÁN PÉREZ, op. cit., p. 187.

65 Así también, SCHMID. En: Müller-Gugenberger, Christian y Klaus BieneCK (eds.) Wirtschaftsstrafrecht. Handbuch des Wirtschaftsstrafrecht- und -ordnungswidrigkeintenrechts, 3. Aufl., Münster: Aschendorff Rechtsverlag, 2000, § 30/77.

to En este sentido, EIDAM, op. cit., pp. 260 y ss.

G Véase supra IV. D. 
que el administrador salve su responsabilidad, siendo exigible que impugne el acuerdo para evitar el daño a la sociedad o sus accionistas o partícipes.

\section{Iter criminis: La intervención en la adopción colectiva de un acuerdo antijurídico: jacto preparatorio, inicio de ejecución o consumación de delito?}

1. El cómo se responde penalmente una vez adoptado el acuerdo que se encuentra condicionado a la existencia de preceptos penales cuya tipicidad consista, exclusivamente, en la adopción de un acuerdo antijurídico («acuerdos ilícitos ejecutivos"). Si estos existen, se estará realizando la acción típica cuando se vota y aprueba la decisión colegiada. Así, todos los que votan a favor serán coautores, ${ }^{68}$ en la medida en que todos participan por igual en la comisión del delito: todos votan en el mismo sentido. Un ejemplo lo constituye el artículo $232 \mathrm{CP}$ que, entre otras modalidad del delito de abuso de poder económico contra la libre competencia, tipifica el participar en acuerdos restrictivos en la actividad productiva, mercantil o de servicios, con el objeto de impedir, restringir o distorsionar la libre competencia. Como se desprende de la literalidad de este precepto, la modalidad transcrita se consuma con la mera aprobación de un acuerdo que, aunque tenga que ser entre varias empresas que participan en el mercado, implica que cada una de ellas acuerde adherirse al pacto restrictivo. En el derecho comparado se conocen también algunos supuestos ${ }^{69} \mathrm{y}$, en el plano nacional, se aprecia también en el ámbito de la administración pública. ${ }^{70}$

* Así GarCía CAVERo, op. cit., p. 351.

69 A modo de comparación, el artículo 291 del Código Penal español establece que «los que, prevaliéndose de su situación mayoritaria en la Junta de accionistas o el órgano de administración de cualquier sociedad constituida o en formación, impusieren acuerdos abusivos, con ánimo de lucro propio o ajeno, en perjuicio de los demás socios, y sin que reporten beneficios a la misma, serán castigados con [...]"; y el artículo 292 del mismo texto legal establece que "la misma pena del artículo anterior se impondrá a los que impusieren o se aprovecharan para sí o para un tercero, en perjuicio de la sociedad o de alguno de sus socios, de un acuerdo lesivo adoptado por una mayoría ficticia, obtenida por abuso de firma en blanco, por atribución indebida de derecho a voto a quienes legalmente carezcan del mismo, por negación ilícita de éste derecho a quienes lo tengan reconocido por la Ley, o por cualquier otro medio o procedimiento semejante, $y$ sin perjuicio de castigar el hecho como corresponde si constituyese otro delito". En estos preceptos se hace expresa mención a los acuerdos $y$, como tales, la participación en uno en las condiciones en que se detallan acarrea responsabilidad penal.

t En todo caso, cabe mencionar, a modo de ejemplo, el artículo $306 \mathrm{CP}$, que se consuma cuando el funcionario público otorga una licencia de funcionamiento para cualquier actividad industrial o cuando, con conocimiento de causa, informa favorablemente para su otorgamiento sin observar las exigencias. Como se dijo (nota 2), es posible que 
2. Si el tipo de lo injusto tiene otra configuración («acuerdos ilícitos que requieren de ulterior ejecución"), lo normal será que la participación en la adopción del acuerdo sea participación en un acto preparatorio cuya punibilidad dependerá del caso en concreto y, sobre todo, de si se ha aprobado y ejecutado el acuerdo. De ser así, el acto preparatorio habrá mutado a inicio de ejecución, ${ }^{71}$ que recién, con arreglo a los artículos 16 y $32 \mathrm{CP}$, es punible. En otras palabras, habrá que evaluar el papel que juega la adopción del acuerdo en la estructura típica de cada delito en particular.

3. Entiendo que cuando se apruebe el acuerdo estaremos, por regla general, en presencia de actos de ejecución y, por ende, de tentativa, sin necesidad de esperar a que este se ejecute. ${ }^{72}$ Ello en función del siguiente razonamiento: a) el momento que separa a los actos preparatorios (impunes) del inicio de la ejecución (punible) debe ser determinado a la luz del tipo de la Parte especial que se trate; ${ }^{73} \mathrm{~b}$ ) los tipos penales que aquí interesan, en cuya estructura se podría encontrar como elemento objetivo del tipo la aprobación de un acuerdo antijurídico, son delitos empresariales, en particular societarios, y es así en la medida en que la actividad empresarial se genera a partir de las actuaciones de los órganos colegiados y estos son parte imprescindible de la estructura organizativa de las sociedades mercantiles; ${ }^{74} \mathrm{c}$ ) la consumación de dichos delitos importará, por regla general, la lesión o puesta en peligro del capital social o de intereses de la sociedad, del patrimonio o intereses de los de los miembros de la sociedad, o de terceros; d) el fundamento de la punición de la tentativa se encuentra tanto en la puesta en peligro inmediata del bien jurídico como en la inmediatez temporal (criterio objetivo), y también en la voluntad del sujeto de conseguir la le-

sean varios los funcionarios que, reunidos en consejo o asamblea, sean los competentes para otorgar la licencia o para informar favorablemente.

$\pi$ SuÁrez González, op. cit., pp. 56-58; Del Rosal BlasCo, op. cit., p. 71; JaKOBS, "Responsabilidad penal..., p. 76, quien señala que "la intervención en una votación, por regla absolutamente general, no es ejecución de un hecho, sino preparación de un hecho, más precisamente, intervención durante la planificación de un hechon; MARTíNEZBUIÁN PÉREZ, op. cit., pp. 187 y ss. y GarCía CAVERO, op. cit., p. 351.

Llega al mismo resultado, WEIßER, op. cit, pp. 165, 190.

73 Welzel, Hanz. Derecho Penal alemán. Parte General, 11. ed., Santiago de Chile: Editorial Jurídica de Chile, 1976, p. 263; MAURACH, Reinhart y otros. Derecho Penal, Parte Ceneral, t. 2, 7. ed. Buenos Aires: Astrea, 1995, $\$ 40 / 16$ ss; MUÑOZ CONDE, Francisco y Mercedes GARCíA ARÁN. Derecho Penal, PG, Valencia: Tirant Blanch, 2002, p. 477 s.; Quintero Olivares, Gonzalo. Manual de Derecho penal, Parte general, 2. ${ }^{a}$ ed., con la colaboración de Morales Prats y Miguel Prats Canut. Pamplona, 2000, pp. 585-587.

74 ANTOLISEI, op. cit., p. 73; SUÁrez GONZÁlez, op. cit., p. 42; Del RoSAl BlasCo, op. cit. pp. 107 y ss.; Martínez-Buján Pérez, op. cit., PE, p. 241. 
sión del mismo (criterio subjetivo); ${ }^{75}$ y e) en conclusión, desde el instante en que se produce la aprobación del acuerdo antijurídico, y no antes, se está en presencia de actos suficientemente importantes como para sostener que el bien jurídico ha sido puesto en un estado de peligro relevante.

4. Además, por razones político-criminales compatibles con la prevención, se debe entender que el derecho penal no puede permanecer inerte frente a un acuerdo cuya ejecución no ofrece dudas sobre una inminente y concreta lesión de bienes jurídicos. En otras palabras, el momento en que los actos preparatorios dejan de ser tales y pasan a ser ya actos propios del inicio de ejecución, habrá que ubicarlo, en el ámbito societario, cuando se conforma la voluntad del directorio al aprobarse el acuerdo ilícito. Pues a partir de ese momento se advierte un estado de peligro inmediato para los bienes jurídicos. Esto se corrobora con la inminencia de la ejecución del acuerdo que, por otra parte, solo puede desencadenar una lesión a bienes jurídicos. Repárese en que si los directores aprueban, con conocimiento de causa, un acuerdo antijurídico, es porque planean ejecutarlo, o planean que otros lo ejecuten. Esto implica - teniendo en cuenta su cargo, conocimientos y experiencia-, que se representan y asumen el riesgo de lesión de bienes jurídicos que entraña tal conducta.

5. En suma, en los casos de acuerdos antijuridicos ejecutivos, la participación en la votación mediante actos encaminados a conseguir la aprobación del acuerdo debe ser considerada ya tentativa de delito, aun cuando el acuerdo no llegue a ser aprobado. En estos casos de acuerdos antijurídicos ejecutivos, la aprobación del acuerdo será ya consumación del delito. ${ }^{76}$ Por otro lado, en los delitos en que la aprobación del acuerdo pueda ser interpretado como un elemento objetivo más de la estructura típica (acuerdos antijurídicos que requieren de ulterior ejecución), habrá tentativa a partir dil momento en que el directorio conforma su voluntad. Dicho con otras palabras, desde que se aprueba el acuerdo antijurídico, sin necesidad de esperar a que este empiece a ser ejecutado. ${ }^{77} \mathrm{La}$ participación en el acto de votación, previa a la aprobación, es -en estos supuestos de acuerdos antijurídicos que requieren de ulterior ejecución - participación impune en un acto preparatorio impune.

T3 En detalle, Welzel, op. cit., pp. 262 y ss; MAURACH y otros, op. cit., 2, §40/26 ss; MIR PUIG, op. cit., L. 13/57; VelÁsquez VelÁsQUeZ, Fernando. Derecho Penal. Parte Ceneral, 3. a ed. Santa Fe de Bogotá: Temis, 1997, p. 597; MUÑ̃oz CONDE y GARCía ARÁN, op. cit., PG, p. 475 y ss. 


\section{Autoría y participación en los supuestos de adopción colectiva de acuerdos antijurídicos}

Con base en lo dicho hasta este momento, se puede concluir:

\section{A. Cuando se trata de acuerdos antijuridicos ejecutivos}

a) Los que votan a favor del acuerdo antijurídico responderán como coautores, al tener todos el mismo rango y contribuir todos con la misma conducta a la realización del delito, y cumplirse los requisitos de tal categoría dogmática, que en estos casos serán fáciles de advertir: el carácter conjunto de la resolución del hecho y de su ejecución. Luego, será coautoría dolosa en tanto los administradores reunidos en el órgano colegiado actúen con conocimiento de que su conducta es peligrosa para el bien jurídico penalmente protegido. Podrá afirmarse una coautoría imprudente si la adopción del acuerdo antijurídico ejecutivo responde a una negligencia de los administradores, aunque la imputación de responsabilidad penal en estos casos, bien es cierto, se encuentre supeditada a la existencia de una modalidad imprudente del delito que se trate.

Entiendo que es dogmáticamente válido considerar a los miembros del órgano colegiado coautores imprudentes, y no tener que afirmar que cada cual, por separado, es autor de un delito imprudente. ${ }^{78} \mathrm{El}$ deber de cuidado le compete, en estos casos, a un colectivo (órgano colegiado, directorio), de manera que tanto su cumplimiento como su vulneración solo puede llevarse a cabo conjuntamente. Lo que no es posible es considerar coautor a quien actúa con dolo juntamente con quien lo hace imprudentemente. Aquí cada cual responde como autor. ${ }^{79}$ También podrán responder como autores o, en su caso, como coautores, aquellos que, sin votar a favor del acuerdo antijurídico, y a pesar de haberlo hecho en contra, en blanco, haberse abstenido o no haber participado en la votación, se les puede atribuir igual responsabilidad penal en mérito del criterio de "el efectivo comportamiento y efectiva voluntad».

b) Quien, sin participar en la votación, induce a error a los miembros del órgano colegiado responde como autor mediato. Esta calificación, no obstante, no siempre será fácil, sobre todo si se tiene en cuenta que los administradores que aprueban el acuerdo antijurídico forman parte de un colectivo que, en la empresa, destaca entre otras circunstancia, por el alto

Así también, para el caso de los órganos colegiados, WEßBER, op. cit., p. 144; RODRíGUEZ MONTAÑES, op. cit., p. 193-194.

79 En el mismo sentido, WeißER, op. cit., pp. 198 y ss. 
grado de conocimiento e información que posee. De ahí, se sigue que podrán surgir complicaciones a la hora de fundamentar el error de tipo invencible, aunque tampoco cabe descartarlo puesto que, en la actuación de los órganos colegiados, muchas veces tiene validez el principio de confianza. Es posible que, llegado el caso, pueda afirmarse autoría mediata en virtud de la coacción, aunque esta posibilidad no se diferenciará de cualquier caso estándar de autoría mediata por coacción.

c) Con todo, cuando se trate de un delito común y el hombre de detrás actúe con dolo, parecerá no haber inconvenientes para que a este se le atribuya responsabilidad como autor mediato y que los administradores (instrumentos) respondan por imprudencia, siempre y cuando se trate de un error de tipo vencible y exista una modalidad imprudente. Si el error de tipo fuera invencible, solo podría ser castigado el autor mediato. En caso de que los miembros del órgano colegiado incurriesen en un error de prohibición, la tipicidad no se verá afectada y el error, de ser vencible, repercutirá solo en la culpabilidad.

Sin embargo, si el delito es especial y el hombre de detrás es un extraneus, habrá que estar a la posibilidad de que se le pueda aplicar la cláusula del actuar en lugar de otro del artículo $27 \mathrm{CP} .^{80}$ Esto será factible en la medida en que el hombre de detrás sea también un órgano directivo de la empresa, ya que de ser así, por lo general será administrador de hecho ${ }^{81}$ o de derecho. Pero será más difícil, aunque no por ello poco frecuente, si se trata de una persona ajena al organigrama empresarial del cual forman parte los miembros del órgano colegiado que adoptan la decisión colegiada. Si fuera así, es decir, si el hombre de detrás fuera un extraneus, y no sea posible aplicarle la cláusula del actuar en lugar de otro, no podrá responder como autor mediato. En este caso, se trataría de un supuesto de inducción dolosa en hecho imprudente ${ }^{82}$ (aprobación del acuerdo antijurídico), cuya argumentación no puede sustentarse en que, al no poder el extraneus ser autor (mediato) por carecer de la cualidad que requiere el tipo, hay que sancionarlo como partícipe (en este caso inductor) para evitar una laguna de punibilidad. Ello solo sería viable si se entendiera que la cualidad que recae en los sujetos

\$ Véase, MEINI MÉNDEZ, Iván. "El «actuar en lugar de otro" en el derecho penal peruanon. NFP, n. ${ }^{\circ} 62,1999$, pp. 127 y ss. Publicado también en Revista jurídica del Perú, n. ${ }^{\circ}$ 28 , noviembre 2001, pp. 127 y ss.

81 Sobre la posibilidad de aplicar el artículo $27 \mathrm{CP}$ para los administradores de hecho, véase ibidem, p. 145.

*2 Argumento que se deriva del principio de unidad del título de imputación, con arreglo al cual los partícipes (extranei e intranei) de un delito especial, propio o impropio, responden como tales, y nunca como autor del delito común. Por todos, GIMBERNAT, Enrique. Autor y cómplice en Derecho penal. Madrid: Universidad de Madrid, 1966, pp. 272 ss. 
activos de los delitos especiales, en virtud de la cual se procede a diferenciar estos delitos de los comunes, es un mero dato formal carente de contenido material. Si, por el contrario, uno se decanta por asumir que la cualidad que exige el tipo de los delitos especiales representa la relación de dominio que existe entre el sujeto activo y el bien jurídico - y que le confiere, con carácter de exclusividad, a quienes participen de dicha cualidad, la posibilidad de vulnerar el bien jurídico como autores - entonces se puede entender que la conducta del intraneus autor mediato, es materialmente distinta, y no solo desde un plano formal, a la del inductor extraneus. No obstante, la sanción penal, en este caso, estará supeditada a que el delito realizado por los administradores, como coautores imprudentes al aprobar el acuerdo antijurídico, se encuentre tipificado en su modalidad negligente. Pero no solo eso, sino que también depende de que el error no sea de tipo invencible, en cuyo caso habrá que concluir en la atipicidad del hecho principal y, por imperio del principio de accesoriedad, en la de la conducta de inducción en tanto participación.

Si se sigue el razonamiento efectuado, se advertirá la paradoja de que la efectiva y real sanción del inductor extranues podrá depender de la diligencia que muestre cuando induce a error a los miembros del órgano colegiado, que en tal estado aprueban el acuerdo antijurídico. En efecto, si el inductor ha engañado "lo suficientemente bien» a los administradores de manera que estos incurran en un error de tipo invencible, no será posible castigarlo porque, en definitiva, no existirá un hecho típico y antijurídico realizado por autor alguno. Pero si, por las circunstancias que fueran, solo ha podido inducirlos a un error de tipo vencible - siempre y cuando exista una modalidad imprudente del delito cometido-, entonces sí procederá su castigo como partícipe.

d) En las hipótesis de que el hombre de detrás sea un intraneus, o cuando, sin serlo, se le pueda aplicar el artículo $27 \mathrm{CP}$, o cuando se pretenda imputar un delito común, en la medida en que el hombre de detrás y los administradores miembros del órgano colegiado actúen dolosamente, no cabe afirmar que todos sean coautores. Pues el hombre de detrás no interviene en la fase de ejecución (que en los supuestos de aprobación de acuerdos antijurídico ejecutivos es el propio acto de aprobación del acuerdo) y tampoco actualiza su dominio en fase ejecutiva. Así pues, el hombre de detrás será inductor, y los administradores que aprueban en acuerdo antijurídico, coautores.

\section{B. Cuando se trata de acuerdos antijurídicos que requieran de ulterior ejecución (delitos en los que el acuerdo antijurídico puede ser aprecia- do como un elemento del tipo)}


a) Si la aprobación del acuerdo responde a una actuación dolosa y este es ejecutado por los mismos directores que lo han aprobado, responderán todos por el delito en grado de tentativa o consumado. Pero la determinación de si lo hacen a título de coautores, cómplices primarios o accesorios, habrá que solventarla analizando la contribución de cada cual en el momento en el que se ejecuta el delito. En las hipótesis de adopción de acuerdos antijurídicos que requieren de posterior ejecución, el hecho de votar a favor del acuerdo es un acto preparatorio, y por ello la persona que se limita a participar en la votación responderá normalmente como cómplice primario (a menos que los miembros del órgano colegiado sean autores mediatos). Ello se debe a que se trata de una aportación imprescindible, pero ubicada temporalmente en el iter criminis en la fase de actos de preparación y no de ejecución del delito. ${ }^{83}$ Con todo, resulta llamativo que se califique de cómplice primario al cerebro o principal responsable (director) que, pese a no estar presente en la ejecución del delito, pero sí en inmediata conexión con ella, la controla y decide su realización. ${ }^{84}$ Para poder considerar al director que participa en la aprobación de un acuerdo ilícito como coautor, habrá que entender que participa en la fase de ejecución del delito, lo cual presupone que la aprobación sea ya tentativa o que actualice su dominio en fase de ejecución. Parece que esto último es lo que ocurre en estos casos, pues la ejecución del acuerdo bien puede ser vista como actualización en fase de ejecución del delito de la imprescindible aportación del director (votar a favor) que se produce en fase de preparación. Aquí, se aprecia que el dominio que el director tiene sobre la organización del delito condiciona ya la forma en que el delito va ha ser ejecutado, y también el resultado mismo del delito. Aun cuando su aportación se haya verificado en fase de preparación y no en fase de ejecución del delito, es posíble considerarlo (co)autor si su dominio se actualiza en la ejecución del delito.

Considerar autor al administrador miembro del órgano colegiado presupondrá que este haya intervenido en la ejecución del acuerdo antijurídico, y que lo haya hecho con el dominio que se requiere para ser autor (dominio, entonces, que se verifica en la ejecución del acuerdo antijurídico). Para decantarse por esta calificación jurídica, resulta irrelevante que el administrador haya intervenido en la votación y haya contribuido con su voto a la

83 Así, WEIßER, op. cit., p. 190. Califican a los que intervienen en la aprobación del acuerdo como coautores, SUÁrez GONZÁleZ, op. cit. p. 58; y MUÑOZ CONDE, "iDominio de la voluntad..., p. 113.

84 MUÑOz CONDE, Francisco. "¿Cómo imputar a título de autores a las personas que, sin realizar acciones ejecutivas, deciden la realiazación de un delito en el ámbito de la delincuencia organizada y empresarial?n. En: Modernas tendencias en la ciencia del Derecho penal y en la Criminología. Madrid: UNED, 2001, p. 510. 
formación de la mayoría necesaria para aprobar el acuerdo, ya que dicha conducta es, en los supuestos de acuerdos antijurídicos necesitados de ulterior ejecución, participación en fase de preparación. Empero, sí resulta suficiente para apreciar cooperación necesaria por parte del miembro del órgano colegiado, toda vez que el intervenir en la sesión en donde se discute el acuerdo antijurídico, y contribuir a su aprobación es un acto fundamental, sin el cual no se habría podido efectuar el delito. Cómplice, en estos casos, es aquel que interviene en fase de ejecución con una aportación prescindible para la realización del hecho punible, por lo que las posibilidades en las que puede hacerlo son infinitas, más aun cuando la ejecución del acuerdo es, siempre en estos casos, un elemento de tantos que tiene el tipo. La tentativa de los cómplices, amén de la accesoriedad cuantitativa, no empezará hasta que no se inicie la del autor. ${ }^{85}$

A pesar de todo ello, en las hipótesis en las que la ejecución del acuerdo antijurídico sea un elemento más de los que componen la tipicidad del delito, determinar si los directores que aprueban el acuerdo son cooperadores necesarios, y quienes lo ejecutan autores, depende, en última instancia, tanto de la estructura típica del delito, como de la específica forma en que el delito se perpetre y de la trascendencia que en la ejecución del delito alcance a tener la ejecución del acuerdo. Puede acontecer, por ejemplo, que la ejecución del acuerdo antijurídico sea un acto sin el cual no se hubiera podido efectuar el hecho, y que el dominio propio de la autoría lo detentaran no quienes ejecutan el acuerdo, sino otras personas que también intervienen en la ejecución del delito con otros actos; o que la ejecución del acuerdo, debido a la particular redacción del tipo y a la forma cómo se realiza el delito, hubiera que ubicarla en fase de preparación del delito.

b) Si se trata de un delito especial y en la ejecución del acuerdo participa un extraneus, este no podrá ser considerado autor. En todo caso, lo dicho anteriormente con ocasión de la ejecución de acuerdos antijurídicos ejecutivos en delito especiales ${ }^{86}$ es también válido en este apartado.

c) El supuesto más frecuente, en el ámbito empresarial, consistirá en que los directivos aprueben el acuerdo ilícito y que los subordinados lo ejecuten desconociendo el sentido final de la directiva u orden. Cabe pensar, pues, que el ejecutor-subordinado podrá actuar imprudentemente en estado de error, debido a la falta de conocimiento y de información propias del colectivo de subordinados; o que, debido a las competencias que asume con la división del trabajo en la empresa, podrá desconocer que la ejecución

* Posición mayoritariamente asumida, véase MAURACH y otros, op. cit., 2, $\$ 50$ n.m. 86 ss.; JAKOBS, Derecho penal, ap. 22 n.m. 19.

* Véase supra VI. A. (c) y (d) 
del acuerdo es, en sí misma, una actividad de riesgo para la indemnidad de bienes jurídicos penalmente protegidos; o que se le dificultará percibir el contenido antijurídico del acuerdo que le ordenan llevar a cabo. Adicionalmente a ello, en diversas ocasiones podrá valorarse como circunstancia que exonere o atenúe la responsabilidad penal del subordinado ejecutor el hecho que haya actuado en estado de necesidad o con miedo insuperable frente a la posibilidad de verse privado de su puesto de trabajo. Todo esto habla a favor de la autoría mediata de los administradores, aunque como se trata de órganos colegiados, será, en puridad, coautoría mediata, ${ }^{87}$ y puede ser esta incluso imprudente.

En todo caso, lo expresado con ocasión del análisis de la autoría mediata e inducción a tenor de los acuerdos antijurídicos ejecutivos, es de aplicación a estos casos, así como también lo dicho respecto a los delitos especiales. Precisamente, en atención a ello, puede darse la situación de que los miembros del órgano colegiado se sirvan de sus empleados subordinados para la realización del delito. De ello se sigue que, si se trata de un delito común, o si siendo un delito especial a los intranei les resulta aplicable la cláusula del actuar en lugar de otro del artículo $27 \mathrm{CP}$, responderán como coautores mediatos. Pero si se pretende imputar un delito especial, y los miembros del órgano colegiado son extranei y no es dable la utilización del artículo $27 \mathrm{CP}$, habrá que apreciar una inducción dolosa en delito imprudente. En las hipótesis de acuerdos antijurídicos que requieren ulterior ejecución, puede presentarse la posibilidad de que el hombre de detrás (con independencia de si es extraneus o intraneus) que induce a error o convence a los administradores para que aprueben un acuerdo antijurídico, sea considerado inductor, y los miembros del órgano colegiado sean considerados autores mediatos dolosos o imprudentes (en tanto ostenten la cualidad que en su caso requiere el tipo especial) del delito que ejecutan sus subordinados. No obstante, en aquellas hipótesis en las que los miembros del órgano colegiado sean inductores de quien ejecuta el acuerdo a título de autor, la eventual responsabilidad penal de los hombres de detrás tendrá que vincularse al hecho principal (de autoría) realizado por el subordinado ejecutor. La razón radica en que no es lícito sostener la punibilidad de participación (inducción del hombre de detrás) en participación (inducción de los miembros del órgano colegiado al subordinado-ejecutor).

87 En el mismo sentido, SUÁrez GONZÁlez, op. cit., p. 58; MUÑOZ CONDE, "¿Dominio de la voluntad..., p. 113; CuADRADO Ruí, María Ángeles. La responsabilidad por omisión de los deberes del empresario. Análisis crítico del art. 363 del Código Penal. Barcelona: Bosch, 1998, p. 122; RODRÍGUEZ MONTAÑÉs, op. cit., pp. 185-195. 


\section{El principio de confianza y el error en la determinación de la responsabilidad penal por la participación en la adopción del acuerdo antijurídico}

1. Así, ¿cuál es, en concreto, el fundamento de la responsabilidad penal de la intervención en la adopción colectiva de acuerdos en una sociedad? Los órganos colegiados son parte de una sociedad y esta, como toda persona jurídica de carácter empresarial, se organiza sobre la base de la división del trabajo y el principio de jerarquía. La información sobre los procedimientos propios del giro empresarial, la decisión de ponerlos en marcha o de paralizarlos y la ejecución de estos, no solo no coinciden en la misma persona, sino que son patrimonio de unos pocos. ${ }^{88}$ Esta peculiar forma de distribuir y organizar el conocimiento se aprecia también en los órganos colegiados. Luego, para la correcta y funcional operatividad del órgano colegial cada miembro desempeñará un círculo de actividad propio, por lo que habrá que determinar en qué medida cada miembro, a la hora de tomar una decisión, se guía por las informaciones que el resto de los miembros proporcione en relación con el cometido especifico que cada uno tenga asignado. ${ }^{89}$ « Hasta qué punto un miembro queda exonerado de responsabilidad por haber votado en favor de la comercialización de un producto que a la postre se demuestra nocivo para la salud, alegando que en su decisión pesó la información que la proporcionó otro miembro del consejo, administrador de laboratorio de la empresa?m. ${ }^{90}$

2. Un sector de la doctrina entiende que acudir a las reglas del error, como en principio cabría pensar, produciría distorsiones en la práctica, por lo que se considera más coherente aplicar el principio de confianza, en cuya virtud cada sujeto puede confiar en que los demás actuarán diligentemente, a no ser que existan indicios concretos que hagan pensar lo contrario. ${ }^{91}$ Sin embargo, una cosa es postular que en mérito a la confianza que debe existir entre los miembros de un determinado colectivo se pueda exonerar de responsabilidad, y otra muy distinta subsumir dicho planteamiento en un mecanismo

* En detalle SCHÜnemanN, Bernd. "Cuestiones básicas de dogmática jurídico-penal y de política-criminal acerca de criminalidad de empresa». ADPCP, 1988, pp. 529 y ss.

* KRAUSE, Daniel-Marcus. Ordnungsgemäßes Wirtschaften und Erlaubes Risiko. Berlin: Duncker, 1995, pp. 412 y ss.; SUÁREZ GONZÁlEZ,op. cit., p. 59. También, MARTíneZBuján Pérez, op. cit., p. 188; NúÑez CASTAÑo, op. cit., p. 164.

90 SuÁrez González, op. cit., p. 59.

9 Ibidem, p. 59; Del. Rosal Blasco, op. cit., pp. 71 y ss.; Pérez Cepeda, op. cit., pp. 314 y ss. Véase la concreción de este principio de confianza para los casos de decusiones colectivas, KUHLEN, Lothar. Fragen einer strafrechtlichen Produkthaftung. Heilderberg: C.F. Müller, 1989, pp. 123-140. 
que pueda ser presentado ante los tribunales. Dicho con otras palabras, el principio de confianza es, como todo principio jurídico, un postulado ideológico, abstracto e inmaterial, que inspira criterios de interpretación y que requiere de un precepto legal para concretizarse y materializarse.

3. Además, en tanto el miembro de un órgano colegiado decide sobre la base de información no verídica o errónea, pero que considera cierta, se encontrará, siempre, en estado de error. No parece lógico que la persona que vota sobre una moción tenga que constatar in situ y personalmente la veracidad de la información que toma en cuenta para decidir su voto, sobre todo cuando la información proviene de otros directores. Por el contrario, se presume que confiará en que quienes le suministran dicha información hayan cumplido con diligencia el rol que les compete según el organigrama empresarial. La información, en estos casos, es proporcionada por fuentes cuya credibilidad se encuentra condicionada por la propia organización del órgano colegiado y de la empresa misma. Luego, el papel que cumpla el principio de confianza será una suerte de razón adicional para poder demostrar el error, que será, en definitiva, la institución jurídico-penal aplicable en estos casos: como la persona que votó a favor del acuerdo lo hizo confiando en la información que le fuera proporcionada por otros miembros del órgano colegiado (miembros respecto de los cuales se podía y debía confiar), el sujeto actúa en error por haber confiado. ${ }^{92}$

q En el mismo sentido, martínez-Buján Pérez, op. cit., p. 189; Núñez Castaño, op. cit., p. 164. 